\title{
Menisküs yırtıklarının artroskopik tamirinde kullanılan dıştan içe teknik
}

\section{Outside-in technique used in arthroscopic repair of meniscus tears}

\author{
Soner Özcan ${ }^{1}$, Hüseyin Kaya², Emin Taşkıran ${ }^{3}$ \\ 1Oltu Devlet Hastanesi, Ortopedi ve Travmatoloji Kliniği, Erzurum \\ ${ }^{2}$ Ardahan Devlet Hastanesi, Ortopedi ve Travmatoloji Kliniği, Ardahan \\ ${ }^{3}$ Ege Üniversitesi Tıp Fakültesi Hastanesi, Ortopedi ve Travmatoloji Anabilim Dalı, İzmir
}

\begin{abstract}
Menisküs yırtıkları en fazla tedavi gören diz yaralanmalarından biridir. Menisküsün artroskopik olarak dikişlerle tamiri üç şekilde yapılabilir; iğnelerin giriş yönüne göre dıştan içe, içten dışa ve tamamı içeride tamirler. Dıştan içe tamir tekniği, özellikle ön boynuz yırtıklarında, meniskal allogreftlerin sabitlenmesinde, fibrin pıhtının meniskal yırtık bölgesine taşınmasında ve menisküs kök yırtıklarının tamirinde kullanılmaktadır. En önemli avantajları diğer yöntemlerle ulaşılması ve dügüum atılması zor olan menisküs anterior $1 / 3$ bölge yırtıklarına ulaşmanın çok kolay olması ve damar sinir paketini korumak için ilave posteromediyal veya posterolateral kesilere gerek göstermemesidir. Bu teknikte iğne giriş noktaları tamamen kontrolümüzde olduğundan, nörovasküler yaralanma riski çok azdır. Bu yöntemin en önemli dezavantajı menisküs arka 1/3'üne uzanan yırtıklara uygulanmasındaki zorluktur. Dıştan içe teknikte iğneler ve dikiş materyali dışarıdan içeri doğru girilerek cilt, kapsül ve menisküs yırtığının dudaklarından geçirilip eklem içine ulaştırılır. Değişik tekniklerle dikişin her iki ucu cilt dışına alınarak kapsül üzerinde subkutan olarak düğüm atılır. Dıştan içe dikişlerin sonuçları diğer tekniklerden pek farklılık göstermemekle birlikte ön ve orta bölge menisküs yırtıklarında kullanıldığında mükemmel klinik sonuç ve yüksek menisküs iyileşme oranı vardır. Dıştan içe menisküs tamir tekniği ucuz, kolay bulunabilen malzemelerle uygulanabilen, öğrenilmesi kolay bir yöntemdir.
\end{abstract}

Anahtar sözcükler: menisküs tamiri; dıştan içe teknik; artroskopi
The meniscus tears are one of the most treated knee injuries. Three types of meniscal repair methods are currently named with respect to the direction that the suture is first passed into the joint: the outside-in, inside-out, and all-inside approaches. The outside-in method can be used especially for the tears in the anterior portion of meniscus, suturing of meniscal replacement (such as an allograft or synthetic device), securing materials such as fibrin clot to a repair site, and tears in meniscal root. The most important advantages of this method are that it is very easy to reach the anterior $1 / 3$ zone ruptures which is difficult to reach with the other methods and difficult to knot, and does not require additional posteromedial or posterolateral cuts to protect the vascular nerve pack. Because the entry point of the needle is controlled, the risk of nerve injury can be minimized as well with use of this method. The main disadvantage of the outside-in method is in treating the tears of the far posterior horn of the meniscus. To begin the outside-in repair, a spinal needle and suture is introduced by piercing the skin and overlying capsule, advancing it under edge of meniscal tears and finally into the joint. After the end of sutures are free they are then pulled back out of knee by the different methods, and sutures are tied over capsule. The results of meniscal repair using the outside-in method show a high rate of healing with excellent clinical results in patients with anterior horn and midbody tears. The outside-in repair method is a technically straightforward, cheap, and simple technique that does not require special equipment.

Key words: meniscal repair; outside-in technique; arthroscopy
M enisküs yırtıkları en fazla tedavi edilen diz yaralanmalarından biridir. ${ }^{[1]}$ Menisküs yırtıklarının tedavisinde, başlangıçta yaralı dokunun tamamının alınması yani total menisektomi amaçlanmış ve cerrahi teknikler bu yönde geliştirilmiştir. Menisküslerin tibianın gereksiz uzantıları olmadığı anlaşıldıktan sonra, yaralanan dokunun tamamının alınması yerine sağlam kalabilecek en fazla dokunun bırakıldığı parsiyel menisektomi yöntemi önerilmiştir. Artroskopi teknolojisinin gelişmesi ile birlikte artroskopik parsiyel menisektomi en fazla uygulanan ortopedik uygulamalardan biri olmuştur. ${ }^{[2]}$

- Illetişim adresi: Prof. Dr. Emin Taşkıran, Ege üniversitesi Tıp Fakültesi Hastanesi, Ortopedi ve Travmatoloji Anabilim Dalı, İzmir Tel: 0532 - 3771385 e-posta: emintaskiran1961@gmail.com

- Geliș tarihi: 1 Mart 2018 Kabul tarihi: 1 Mart 2018 


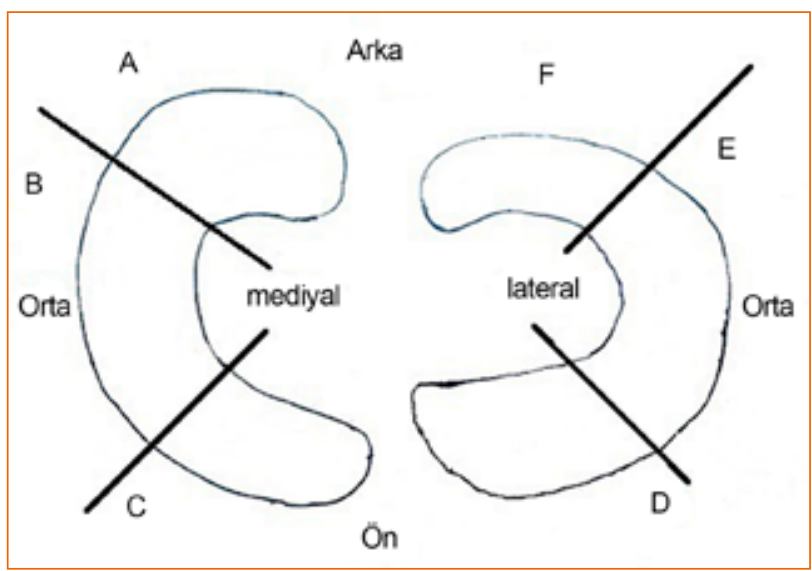

Şekil 1. Menisküs yırtıklarının yerini tanımlamak için Cooper sınıflaması: mediyal menisküs ve lateral menisküs ön, orta ve arka boynuz olarak radyal bölümlere ayrılmış.

Menisküslerin tamir edilerek korunmaları konusundaki deneyimler çok eskilere dayanır. Menisküslerin dizde yük taşıma ve aktarma konusunda önemli görevlerinin olduğunun anlaşılması ve total menisektomi sonrası ortaya çıkan artritik değişiklikler, hasarlı menisküslerin onarılması seçeneğine olan ilgiyi arttırmıştır. illk menisküs tamiri 1885 yılında Thomas Annandale tarafından yayımlanmasına rağmen seksenli yıllara kadar menisküs tamiri ilgi görmemiştir. ${ }^{[3]}$ DeHaven ve ark. tarafından açık menisküs tamirlerinin uzun dönem başarılı sonuçlarının ortaya konması ile bu konudaki çalışmalar hızlanmıştır. Önceleri açık yapılan tamirler, teknolojinin gelişmesi ve cerrahların bu konudaki becerilerinin artması sonucu artroskopik yapılabilir hale gelmiştir. Tamir endikasyonu olan bütün yırtıklarda uygulanabilmesi yanında, artroskopik yöntemde sıklıkla özel enstrümantasyona, cerrahi deneyime ve bilgili bir asistana ihtiyaç duyulmaktadır. ${ }^{[4]}$

Menisküs yırtıklarının artroskopik olarak dikişlerle tamiri üç şekilde yapılabilir; iğnelerin giriş yönüne göre dıştan içe, içten dışa ve tamamı içeride tamirler. Her bir metodun kendine göre artıları ve eksileri olmakla birlikte, tekniğin seçiminde bunlar dikkate alınarak, yırtığın durumuna göre bir veya birkaç metod beraber kullanılabilir.

Dıştan içe tekniği ilk defa 1985 yılında Warren tarafindan lateral menisküs tamirinde peroneal sinir hasarlanması riskini azaltan bir metod olarak tanımlanmıştır. Adından da anlaşılacağı gibi, bu metodda iğneler ve dikiş materyali dışarıdan içeri doğru girilerek cilt, eklem kapsülü ve yırtık menisküsün her iki parçası geçilir. Metodun ayrıntısına göre dikiş çeşitli şekillerde düğümlenerek yırtık parçaları stabilize edilir. Bu tamir yönteminde çeşitli teknikler kullanılmakla birlikte, hepsinde eklem kıkırdağı ve nörovasküler yapıları hasarlama riskini en aza indirmek amaçlanır ve ekleme girmek için bir spinal iğne veya içinden iplik geçebilecek kalınlıkta bir iğne kullanılabilir. ${ }^{[5]}$

\section{Tekniğin Kullanım Alanları}

Menisküsün ön ve orta $1 / 3$ kırmızı-kırmızı alanındaki vertikal longitudinal yırtıklarında (Şekil 1), semptomatik Wrisberg tip diskoid menisküs cerrahi tedavisinde, menisküs iyileşme potansiyelini arttırmak için kullanılan fibrin pıhtısının yırtık bölgesine taşınmasında ve meniskal allogreft ya da sentetik skafoldların kapsule dikilmesinde, dıştan içe teknik kullanılabilir. ${ }^{[6,7]}$

Menisküs arka $1 / 3$ yırtıklarında bu bölgeye ulaşmak bu teknikle zor olduğundan, ulaşılsa bile yırtık hattına dik olunamadığından ve nörovasküler hasar riski nedeniyle önerilmemektedir. Ayrıca; doku kalitesi bozulmuş kronik yırtıklarda, menisküs kırmızı-beyaz veya beyaz-beyaz alandaki yırtıklarda ve özellikle ön çapraz bağ yetmezliği gibi dizde bağ yaralanmasına bağlı instabilite durumunda, bağ tamiri yapılmadan izole menisküs tamiri önerilmemektedir. ${ }^{[8]}$ Ancak son yıllarda, ekipman ve dikiş geçiricilerdeki yetersizlik ve eklemin yeterince açılamadığı durumlarda menisküs kök yırtıklarının tamirinde de kullanılabilir.

\section{Tekniğin Avantaj ve Dezavantajları}

Dıştan içe tamir tekniği, bir spinal iğne dışında özel bir enstrümantasyona ihtiyaç duyulmayan ucuz ve kolay uygulanan bir tekniktir. Spinal iğnelerin geçirilmesi sırasında iğnelerin eklem yüzeylerinde kıkırdak hasarı oluşturma riski olmasına karşın, sert kanüller kullanılmadığından diğer yöntemlere göre bu risk daha azdır. Çocuklardaki semptomatik Wrisberg tip diskoid menisküs tedavisinde olduğu gibi dar ve küçük dizlerde de diğer yöntemlere göre kullanımı kolaydır. Dikişleri bağlamak için çok küçük kesiler kullanıldığından, cerrahi travma azdır. Lateral menisküs yırtıklarının tamirinde peroneal sinir hasarlanma riski de azdır.

Bu yöntemin en önemli dezavantajı, menisküs arka 1/3'üne uzanan yırtıklara uygulanmasındaki zorluktur. Kullanılan dikiş materyalinin spinal iğne içinden geçme zorunluluğu olduğundan, emilemeyen örgülü dikişlerin kullanılması polidiaksanon (O-Polydioxanone, ETHICON; Somerville, NJ, USA) gibi monofilaman sütürlere göre zordur. Ayrıca, kova sapı yırtıklarının tamirinde önce deplase parçanın redükte edilmesi gerektiğinden, bu işlem sırasında redüksiyon amaçlı dıştan içe dikiş yerine içten dışa dikiş tekniği tercih edilmektedir. 


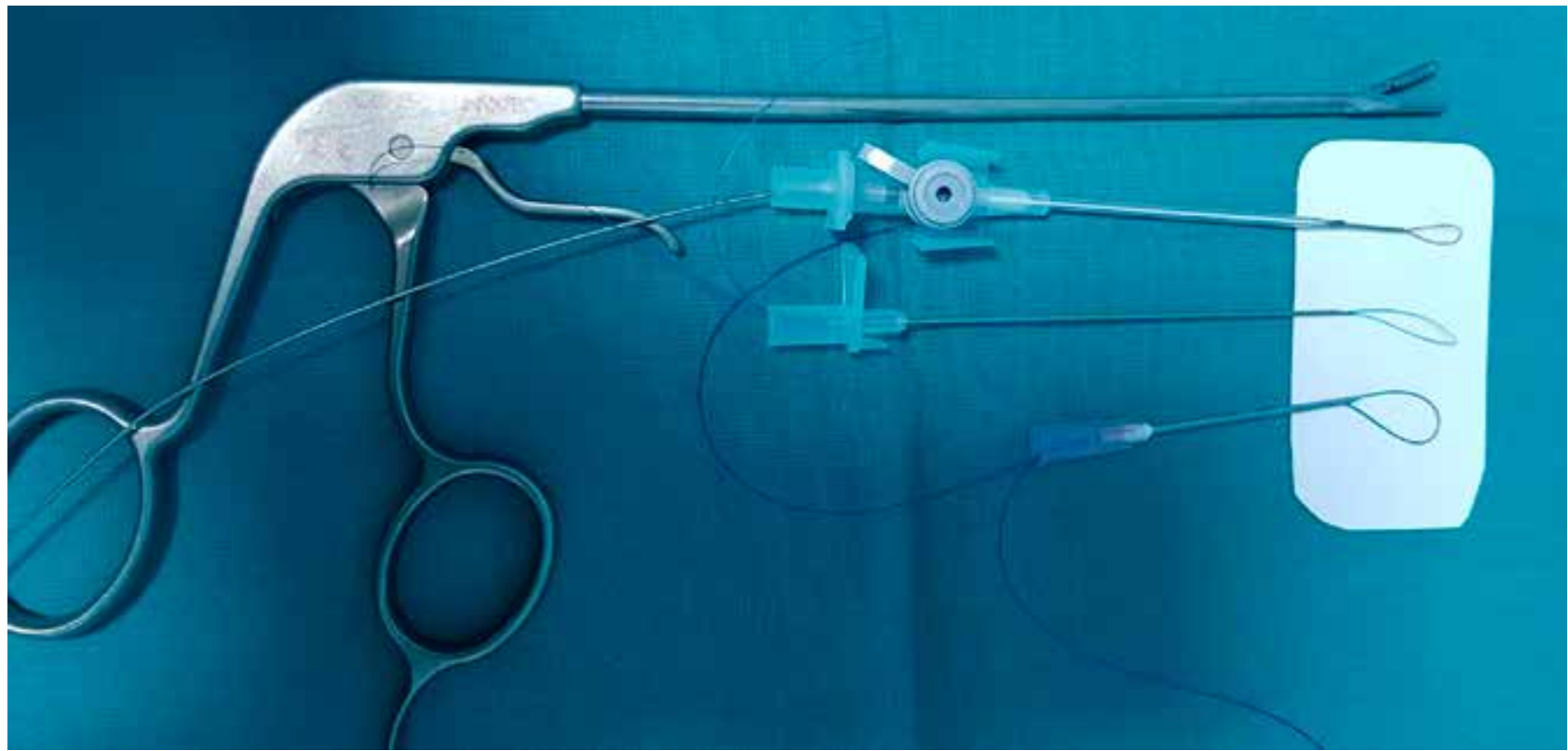

Şekil 2. Dıştan içe menisküs tamirinde kullanılan aletler.

\section{Ameliyat Öncesi Hazırlık}

Menisküs tamirlerinde birden fazla seçenek olduğundan, cerrahi sırasında tekniklerin ve kararların değişebileceği hastaya söylenmelidir. Hastaya, dikiş planı ile cerrahiye başlanılacağı, fakat tamir konusundaki kesin kararın ameliyat sırasında verilebileceği anlatılmalıdır. Eğer tamir yapılırsa, morbiditenin parsiyel menisektomiden farklı olacağı ve ameliyat sonrasındaki kısıtlamaların daha fazla olacağı anlatılmalıdır. Özellikle yüksek motivasyonlu genç sporcularda, ameliyat sonrası morbidite ve spora dönüş süresi konuşulmalıdır.

\section{DIŞTAN IÇE MENISKÜS TAMIRI}

\section{Anestezi ve Pozisyon}

Bölgesel anestezi sonrası, hareket açıklığı ve bağ stabilitesi açısından, önce anestezi altında sağlam ve yaralı dizin muayenesi yapılmalıdır. Turnike kullanımı cerrahın tercihine bağlı olmakla birlikte, kullanılmasa da uylukta sarılı hazır olmalıdır. Hastanın bacağı, dikişlerin her iki taraftan kısıtlanmadan gönderilmesi için masanın ucundan aşağı sarkıtılmalı ve serbest olmalıdır. Bacak tutucu kullanılacaksa, diz fleksiyonunun engellememesi açısından mümkün olduğunca proksimale takılmalıdır. Bacak tutucu kullanılmayacaksa, mediyal menisküs görüntülemesi açısından yan destek kullanılmalıdır.

\section{Ekipman}

Menisküs dikişlerinde genelde kullanılan tıraşlayıcı, raspa, kesici-koparıcı ve tutucu aletlere ek olarak öncelikle dikişi içeri iletecek delici malzemelere ihtiyaç vardır. Bunun en basit ve ucuz olanı 18G-20G kan enjektörleridir. Bu iğnelerde dikişi içeri sokmak zor olmakla birlikte, teknikte anlatılacak yöntemle dikişin bir kısmını ucundan çıkarıp cildi perfore ederek bu sorun çözülebilir. 22G spinal iğne ve $18 \mathrm{G}$ epidural iğnelerde bu sorun olmamakla birlikte, iğnelerin uzun olması nedeniyle kontrol zordur. ${ }^{[9]}$ Özel olarak geliştirilen dikiş setlerinde, düz ve açוlı iğneler ve dikişi içerde yakalamak için tel halkalı iğneler bulunmaktadır (Meniscal Mender) (Smith and Nephew ${ }^{\mathrm{TM}}$, Memphis, TN, USA) (Şekil 2).

Dikiş materyali olarak emilmeyen örgülü $2 / 0$ dikişler tercih edilmelidir. Ethibond benzeri (Polyester Sutures, ETHICON) veya kopma dirençleri daha kuvvetli olan polyester dikişler ULTRABRAID 2/O (Cobraid, Smith and Nephew $^{\mathrm{TM}}$, Memphis, TN, USA) veya fiberwire (Artrex ${ }^{\mathrm{TM}}$, Naples, FI, USA) kullanılabilir. Örgülü dikişlerin dışarıdan içeri geçişlerinin zorluğu nedeni ile, Prolene (Polypropylene Sutures, ETHICON) gibi emilemeyen monofilaman sert dikişler de bulundurulmalıdır.

\section{Teknik Basamakları}

Standart anteromediyal ve anterolateral portaller uygulama için yeterlidir. Dizin tam bir artroskopik muayenesi yapılarak; ön ve arka çapraz bağlar, her 

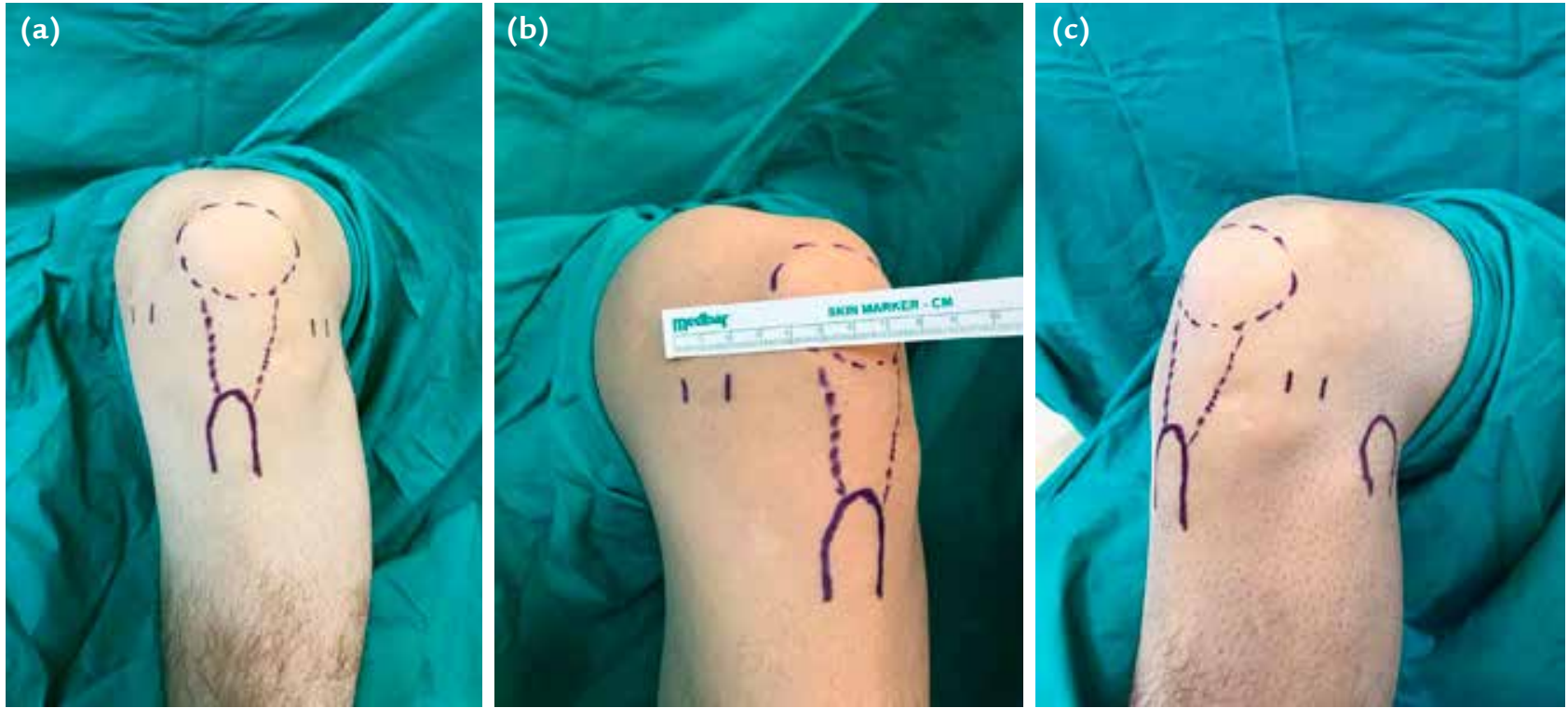

Şekil 3. a-c. Mediyal ve lateral menisküs ön boynuz ve orta bölüm tamirlerinde dıştan içe teknikte iğne giriş yerleri ve ipler için longitudinal 1 cm'lik iki insizyonun görüntüsü: sol diz ön (a), mediyal (b) ve lateral görüntü (c).

iki menisküs ve her üç kompartmandaki kıkırdak yüzler ayrıntılı değerlendirmelidir. Mediyal ve lateral menisküslerin üst ve alt yüzleri parsiyel ve tam yırtıklar açısından değerlendirilmeli ve stabilitesi kontrol edilmelidir. Posteromediyal ve posterolateral kompartmanlar kök yırtıkları açısından ayrıntılı incelenmelidir. İşleme başlamadan önce, prob ile dikilecek alanlara ulaşılabilirlik kontrol edilerek, uygulanacak tekniğe karar verilir. İyi bir teknik, dikilecek menisküs parçası ve yatağının iyice hazırlanması ile başlar. ${ }^{[9]}$

Öncelikle yırtığın her iki kenarı 3,5 mm ince tıraşlayıcı ve artroskopik törpü yardımıyla canlandırılmalı, küntleşen kenarlar skar dokusundan temizlenmelidir. Çevresel damarsal yapıların avasküler bölgeye ulaşabilmesi amacıyla, spinal iğne ya da özel aletler aracılığıyla, yırtığın periferde kalan dudağından kapsüle doğru 4-5 mm aralıklarla tüneller açılır. Ayrıca, yırtık alanına komşu sinovyanın tıraşlanmasının yeni damar oluşumunu ve kök hücrelerinin dikiş bölgesine gelmesini arttırdığı gösterilmiştir. ${ }^{[10]}$

Yırtık dudakları hazırlandıktan sonra, eğer deplase bir yırtık ise, künt trokar yardımıyla redüksiyon yapılarak periferik yatak ile uyum sağlanır. Yırtık, kova sapı yırtıksa; dıştan içe teknikten ziyade içten dışa teknikle redüksiyon dikişi uygulanır. Redüksiyon sonrası menisküse konulacak dikiş sayısı ve yeri yaklaşık olarak tasarlanır.

Dikişin nasıl konulacağı ile ilgili birçok çalışma yapılmıştır. Horizontal dikişte, her iki dikiş, parçaların her ikisinden de geçer. Vertikal dikişte, dikişlerden biri redükte yırtık parçasından ve kapsüler parçadan geçerken, diğer dikiş kapsüle yakın menisküs kenarından geçer. Vertikal dikişlerin horizontal dikişlere göre yük altında daha az hareket özelliği ve çevresel kollajen liflerini dik olarak sarması nedeniyle daha kurvetli olduğu gösterilmiştir. Önerilen dikiş aralıkları 4-5 mm olmakla birlikte, alt veya üst yüzeye uygun sayıda ve sırada atılmalıdır. ${ }^{[11-13]}$

Bu yöntemin en önemli avantajlarından biri, içerden ışıklandırma (transillüminasyon) ile cilt üzerinde uygun nokta saptanarak giriş yerinin kolayca belirlenmesi nedeniyle, mikrovasküler hasar riskinin en az olmasıdır. Bir probun eklem içinden ciltte kabarıklaşma oluşturacak şekilde kullanılması veya cildin palpasyonu ile kapsülün içerden hareketinin izlenebilmesi, iğnenin giriş yerini belirlemede yardımcı yöntemlerdir.

Yukarıda bahsedilen iğnelerden biri dışarıdan içeri girecek şekilde, menisküs redükte poziyonda iken ve menisküse içerden karşı basınç uygulanarak cilt, kapsül ve menisküs yırtığının dudaklarından geçirilip eklem içine ulaştırılır. illk iğne girildikten sonra, cilt iğne giriş yerinden itibaren $1-1,5 \mathrm{~cm}$ kadar açılarak ve ince klemp ile künt disseksiyon yapılarak kapsüle kadar ulaşılır. İkinci dikiş, istenilen yön ve planda, genellikle ilk iğnenin $1-1,5 \mathrm{~cm}$ uzağından girilerek aynı şekilde eklem içine ulaşılır (Şekil 3). Bu şekilde cilt giriş yerleri birbirine yakın tutularak, iğnenin menisküsten çıkış yerinin istenilen açı ve yönde olması sağlanabilir. İğnenin eklemde 
çıkış yerinin, avasküler olması ve tansiyon altında yırtılma ihtimalinin yüksek olması nedeniyle, menisküsün iç kenarında olmamasına özen gösterilmelidir.

Daha önce de bahsedildiği gibi, bu teknikte iğne giriş noktaları tamamen kontrolümüzde olduğundan, nörovasküler yaralanma riski çok azdır. Lateral menisküs ön ve orta bölüm yırtıklarının tamirinde, iğne giriş yeri peroneal sinir hasarını önlemek için biseps tendonu önünde olmalıdır. Daha posteriordaki yırtıkların tamirinde ise, eğimli spinal iğnelerin kullanılması bu riski azaltacaktır. Dizi $90^{\circ}$ 'ye alarak peroneal sinirin posteriora yer değiştirmesi sağlanmalıdır.

Mediyal menisküs yırtıklarının tamirinde ise, safen sinir ve ven risk altındaki yapılardır. Diz eklem çizgisinin $10 \mathrm{~cm}$ yukarısında safen sinir yüzeyel hale gelip infrapatellar ve sartorial dallarına ayrılır; infrapatellar dalı en fazla yaralanan daldır. Semitendinosus tendonunu arka sınırından çaprazlayıp dizin anterolateral duyusunu almak için öne doğru seyreder. Diz eklem çizgisi seviyesinde semitendinosus tendonunun hemen önünde seyreder ve dizi $10^{\circ}$ ekstansiyonda tutmak bu yapıları çalışma alanımızın ön tarafına alır. Menisküs posterior 2/3 yırtıklarının tamirinde nörovasküler yaralanmadan sakınmak için, iğne giriş yeri semitendinosus tendonunun arkasından olmalıdır. Menisküs anterior $1 / 3$ yırtık tamirinde ise, diz $50-60^{\circ}$ fleksiyona alınıp iğne giriş yeri pes anserinus tendonları ve safen sinir dallarının anteriorunda olmalıdır. Anteromediyal portale gereklilik halinde, araya yumuşak doku girmesini önlemek için $7 \mathrm{~mm}$ çalışma kanülü konulabilir.

Dikişlerin geçirilmesi ile ilgili üç teknik tanımlanmıştır. İki serbest uç tekniğinde, uygun şekilde menisküsten geçirilen iğnelerden birinin içinden tel halka geçirilip eklem içine yönlendirilir. Dikiş anterior portalden tutucu yardımıyla artroskopik olarak halka içine yerleştirilir. Tel halka menisküsten dışarı doğru çekilerek, dikişin bir ucu cildin dışına alınır. Aynı işlem, anterior portal dışında olan dikişin diğer ucu için tekrarlanır. İğneler cilt dışına alınarak kapsül üzerinde subkutan olarak düğüm atılır (Şekil 4 ve 5). Ticari olarak tel halka temin edilemiyorsa, polidiaksanon (0-Polydioxanone, ETHICON; Somerville, NJ, USA) dikiş iğneden eklem içine yönlendirilip karşı portalden cilt dışına alınarak taşıyıcı ip olarak kullanılabilir. ${ }^{[14]}$

Halkalı teknikte ise, bir iğneden dikiş diğer iğneden tel halka eklem içine yönlendirilir. Tutucu yardımıyla tel halka içinden geçirilerek cilt dışına alınıp kapsül üzerinde düğüm atılır. ${ }^{[15]}$

Mullberry düğüm olarak bilinen teknik, kolay olmasına karşın kuvvetinin az olması ve düğümlerin eklem içinde kalması nedeniyle pek tercih edilmemektedir. Bir tutucu ile alet portalinden dışarı alınan dikişin, dışarıda çoklu bir düğüm ile kalınlaştırılarak ve menisküs üzerine çekilerek oturtulmasıdır.[16,17]

Dikişler geçildikçe, her bir dikişe iki ucundan bir klemp asılır. Pıhtı uygulaması yapılacaksa, bu aşamada periferik parçadan geçen tek dikiş alet portalinden geniş bir kanül içinden dışarı alınarak pıhtı bağlanır, diz içine ve parçalar arasına çekilir, menisküsler redükte edilerek pıhtı araya sıkıştırılır. Örgülü dikişlerde en az dört, monofilaman dikişlerde en az altı düğüm atılmalıdır. Menisküsün fleksiyonda arkaya hareketi göz önüne alınarak menisküs anterior $1 / 3$ yırtıklarında dügümler ekstansiyona yakın, orta $1 / 3$ yırtıklarda $90^{\circ}$ 'ye yakın bağlanmalıdır. Dikişler düğümlendikten sonra prob ile menisküsün stabilitesi kontrol edilmeli gerekirse ek dikiş atmaktan kaçınılmamalıdır. Ön çapraz bağ rekonstrüksiyonu ile beraber yapılan menisküs tamirlerinde genel kabul, dikişlerin önce geçirilmesi ancak bağlanmaması, bağ rekonstrüksiyonu sonrası son aşamada bağlanması yönündedir.

Menisküs arka kökün dıştan içe tamir tekniğinde ise, ayrıca bir posteromediyal portal açılmamakla birlikte, eğri kanüllü spinal iğne bu portal lokalizasyonundan eklem içine sokulur. Menisküsün yırtık olan kök kısmının yaklaşık olarak 3-5 mm mediyalinden üst yüzden alt yüzüne doğru iğne ilerletilir. İğne alt yüzün dışına çıktığında dikişiğnenin içinden sokulur. Anteromediyal portalden sokulan bir yakalayıcıyla naylon ip dışarı alınıp portalin dışında güçlü bir ipe bağlanır. Güçlü ipin bir bacağı naylon ip vasıtasıyla posteromediyalden dışarı alınır. Dışarı alınan bu bacak, anteromediyal portalden sokulan prob ve yakalayıcı yardımıyla menisküsün üst yüzünde yakalanıp yeniden eklem içine, buradan da anteromediyal portalden dışarı alınır. Aynı işlem bir kez daha tekrarlanarak, menisküsten iki basit dikiş dıştan içe tekniği ile geçirilmiş olur. Daha sonra, iplerin serbest uçları tibia anteromediyaline açılan tünelden geçirilerek; uygun gerilim altında menisküsün redükte edildiği kontrol edilip post vidasına bağlanır (Şekil 6 ve 7).

\section{Komplikasyonlar}

Hastalar başlangıçta nörovasküler yaralanmalar ve hareket kaybı konusunda uyarılmalıdır. Lateral menisküs tamiri sırasında peroneal sinir hasarı olmakla birlikte, iğne girişi sırasında dizi $90^{\circ}$ 'ye almak ve biseps tendonunun önünde bir yerde giriş yapmakla bu risk azaltılır. Mediyal menisküs tamiri sırasında safen sinir hasarı riski olup, transillüminasyon yöntemi ile anatomik bölgenin işaretlenmesi ve düğüm atılma sırasında kapsüle kadar künt disseksiyon yapılması bu riski azaltır. İçeriden dışa ve tamamı içerde dikiş teknikleriyle tamirleri önerilmesine rağmen, menisküs posterior $1 / 3$ yırtıklarında dışarıdan içeri tekniği 

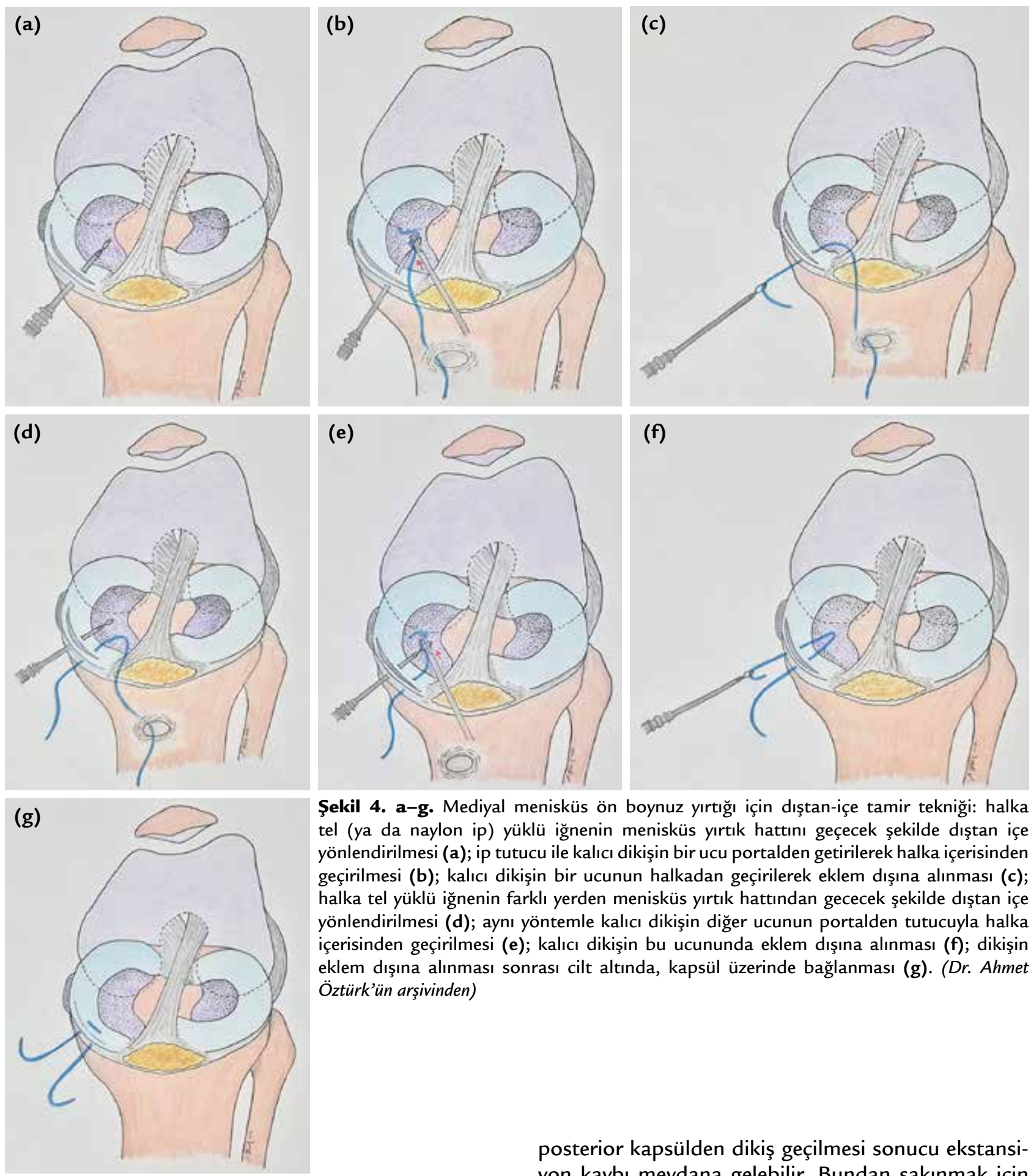

Şekil 4. a-g. Mediyal menisküs ön boynuz yırtığı için dıştan-içe tamir tekniği: halka tel (ya da naylon ip) yüklü iğnenin menisküs yırtık hattını geçecek şekilde dıştan içe yönlendirilmesi (a); ip tutucu ile kalıcı dikişin bir ucu portalden getirilerek halka içerisinden geçirilmesi (b); kalıcı dikişin bir ucunun halkadan geçirilerek eklem dışına alınması (c); halka tel yüklü iğnenin farklı yerden menisküs yırtık hattından gececek şekilde dıştan içe yönlendirilmesi (d); aynı yöntemle kalıcı dikişin diğer ucunun portalden tutucuyla halka içerisinden geçirilmesi (e); kalıcı dikişin bu ucununda eklem dışına alınması (f); dikişin eklem dışına alınması sonrası cilt altında, kapsül üzerinde bağlanması (g). (Dr. Ahmet Öztürk'ün arşivinden)

kullanıldığında, posterior nörovasküler yapıların yaralanma riski vardır. Eğri spinal iğne kullanılarak ve dikişleri oblik yönde geçirerek bu risk azaltılabilir. Dikiş uygulama sırasında aşırı fleksiyona bağlı olarak posterior kapsülden dikiş geçilmesi sonucu ekstansiyon kaybı meydana gelebilir. Bundan sakınmak için diz tam ekstansiyona yakın alınır.

\section{Klinik Sonuçlar}

Menisküs yırtıklarının dışarıdan içeri teknikle tamirinin klinik olarak sonuçlarının değerlendirildiği çalışmalarda, tamirin semptomatik anlamda iyileşmeye yol açtığı ve hastaların işlevsel kapasitelerinin arttığı belirtilmektedir. Ancak, subjektif olarak yapılan bu 

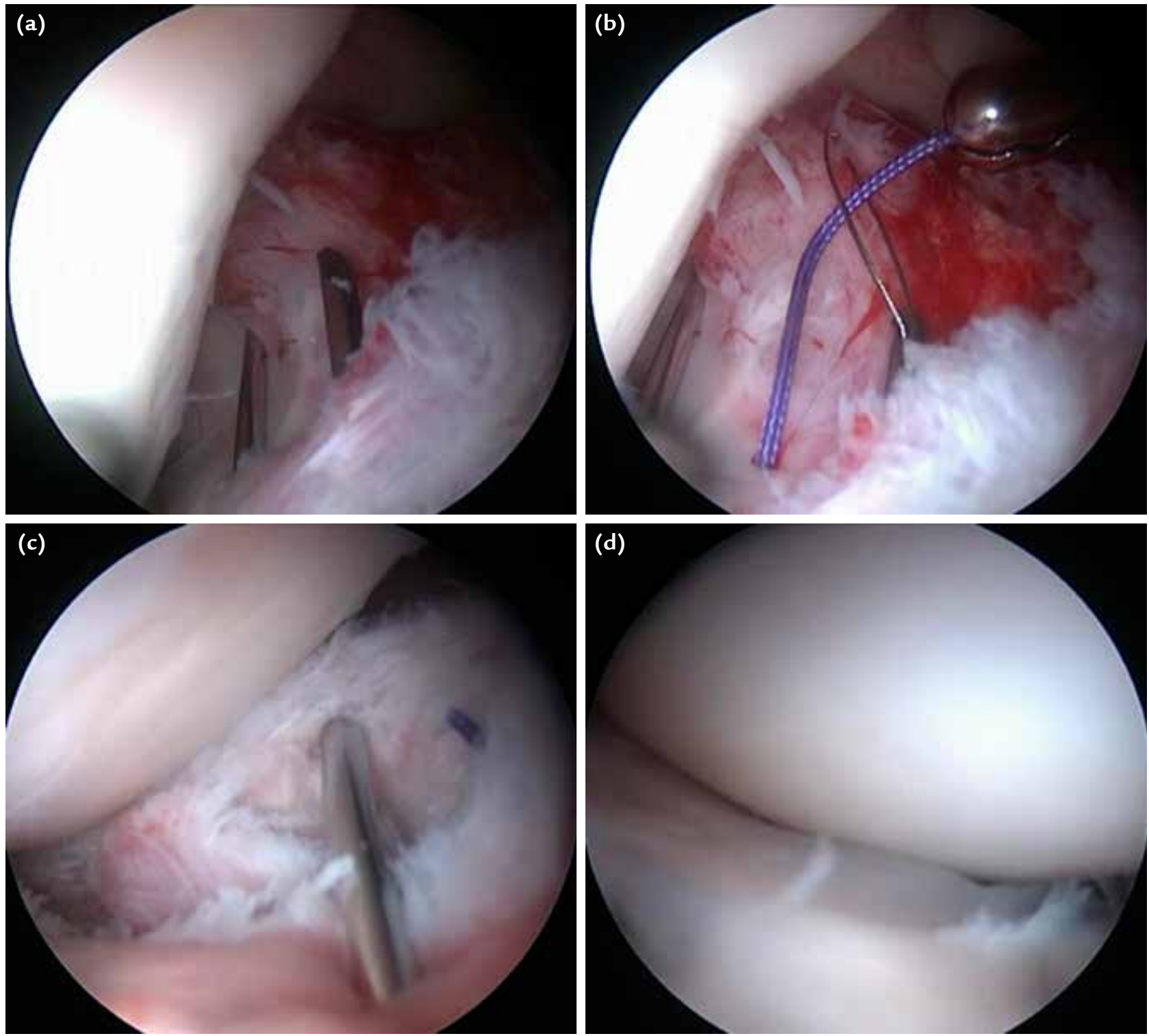

Şekil 5. a-d. Sağ diz lateral menisküs meniskokapsüler bölgedeki yırtığın dıştan içe tamir tekniğinin artroskopik görüntüleri: dıştan içe iki adet iğnenin ilerletilmesi (a); dikişin bir tutucu yardımıyla portalden getirilerek birinci iğneden çıkan tek halkadan geçirilmesi ve çekilerek eklem dışına alınması (b); ikinci iğneden aynı işlemlerle dikişin diğer ucunun eklem dışına alınması (c); eklem dışında ipin uçlarının bağlanarak menisküsün redükte edilmesi (d).

klinik değerlendirmelerin, objektif olarak her koşulda doğrulanamamış olduğu görülmektedir. Ameliyat sonrası dönemde değerlendirmenin manyetik rezonans görüntüleme ya da ikincil bakış artroskopisi ile yapıldığı çalışmalarda, tamirin her olguda başarılı sonuç vermediği, yırtıkların tamamının iyileşmediği belirtilmektedir.

Morgan ve ark.'nın dışardan içeri menisküs tamiri uyguladıkları 353 olguluk serilerinde klinik iyileşme oranı \%84 olarak bulunmuştur. Yazarlar, semptomsuz hastalara yapılan ikincil bakış artroskopisinde, \%65 oranında tam iyileşme ve \%19 kısmi iyileşme rapor etmişlerdir. İyileşmeyen grubun hepsinde ön çapraz bağ yetmezliği bulunmakla birlikte tüm yırtıkların menisküs posterior $1 / 3$ 'ünde olduğunu bildirmişlerdir. Ön çapraz bağı sağlam olan ya da rekonstrükte edilen grupta başarısız sonuç saptanmamış olup, tam iyileşme dört aylık zaman diliminde gözlenmiştir. ${ }^{[18]}$ 

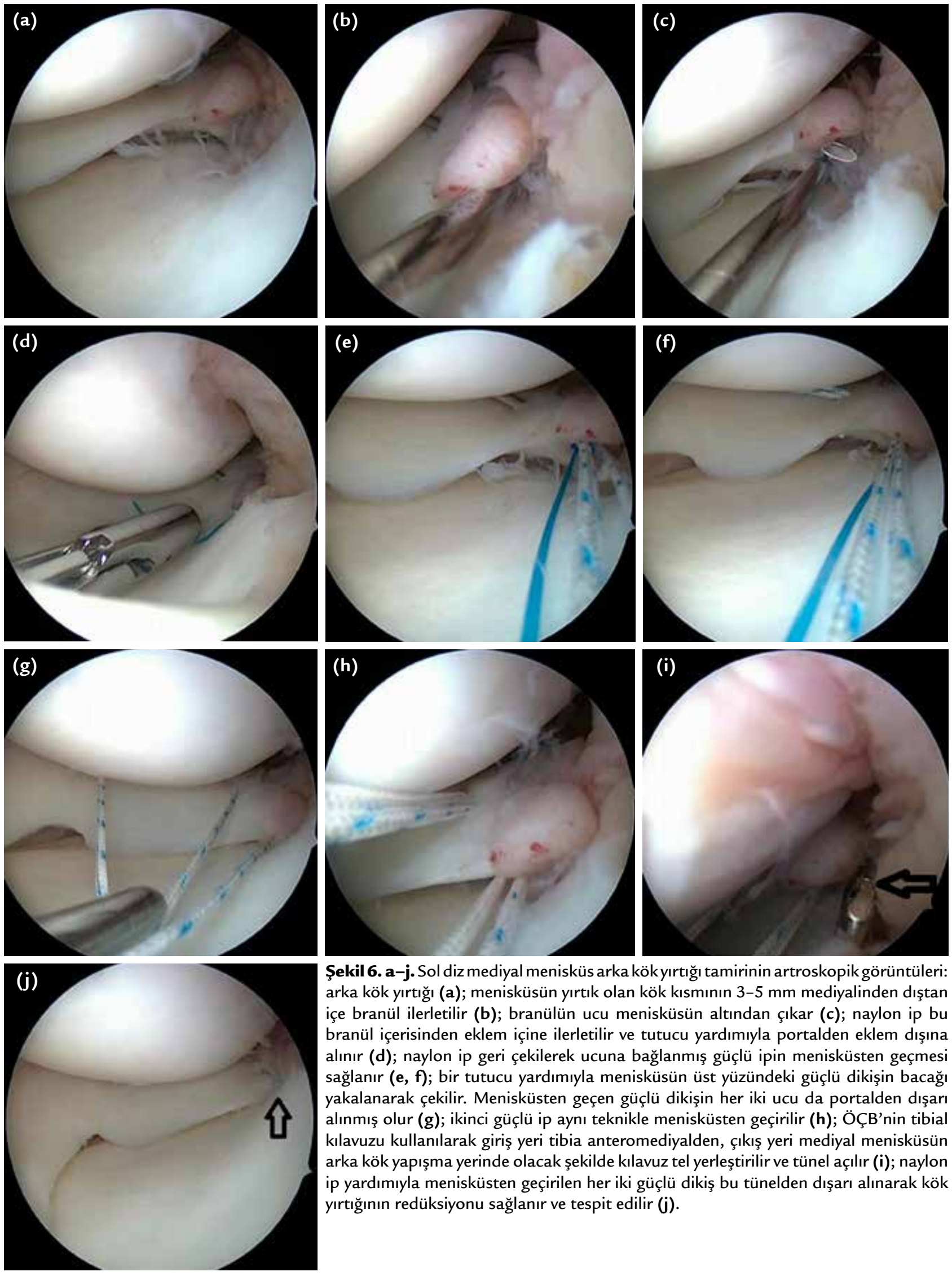

Şekil 6. a-j. Sol diz mediyal menisküs arka kökyırtığı tamirinin artroskopik görüntüleri: arka kök yırtığı (a); menisküsün yırtık olan kök kısmının 3-5 mm mediyalinden dıştan içe branül ilerletilir (b); branülün ucu menisküsün altından çıkar (c); naylon ip bu branül içerisinden eklem içine ilerletilir ve tutucu yardımıyla portalden eklem dışına alınır (d); naylon ip geri çekilerek ucuna bağlanmış güçlü ipin menisküsten geçmesi sağlanır (e, f); bir tutucu yardımıyla menisküsün üst yüzündeki güçlü dikişin bacağı yakalanarak çekilir. Menisküsten geçen güçlü dikişin her iki ucu da portalden dışarı alınmış olur (g); ikinci güçlü ip aynı teknikle menisküsten geçirilir (h); ÖçB'nin tibial kılavuzu kullanılarak giriş yeri tibia anteromediyalden, çıkış yeri mediyal menisküsün arka kök yapışma yerinde olacak şekilde kılavuz tel yerleştirilir ve tünel açılır (i); naylon ip yardımıyla menisküsten geçirilen her iki güçlü dikiş bu tünelden dışarı alınarak kök yırtığının redüksiyonu sağlanır ve tespit edilir (j). 

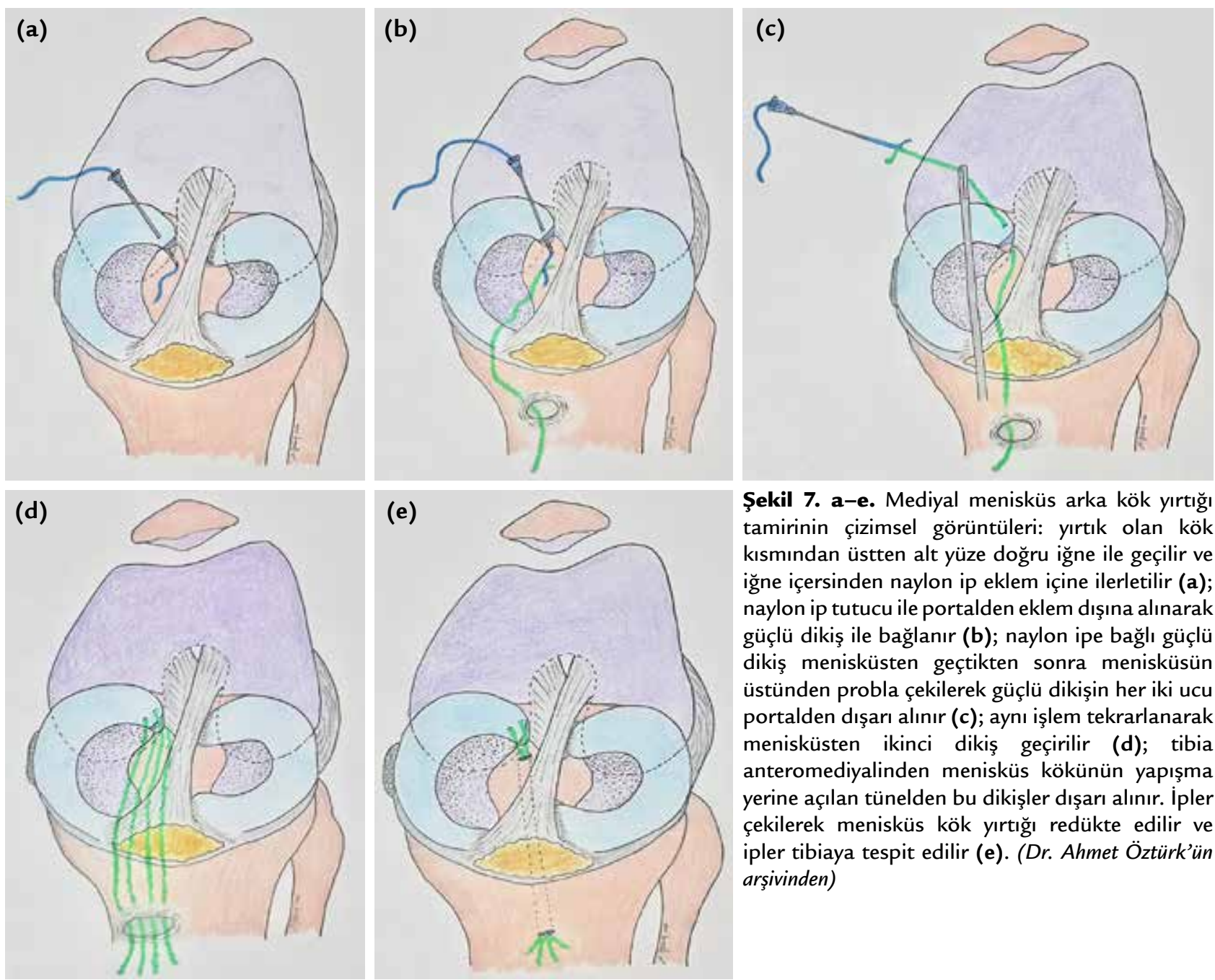

Şekil 7. a-e. Mediyal menisküs arka kök yırtığı tamirinin çizimsel görüntüleri: yırtık olan kök kısmından üstten alt yüze doğru iğne ile geçilir ve iğne içersinden naylon ip eklem içine ilerletilir (a); naylon ip tutucu ile portalden eklem dışına alınarak güçlü dikiş ile bağlanır (b); naylon ipe bağlı güçlü dikiş menisküsten geçtikten sonra menisküsün üstünden probla çekilerek güçlü dikişin her iki ucu portalden dışarı alınır (c); aynı işlem tekrarlanarak menisküsten ikinci dikiş geçirilir (d); tibia anteromediyalinden menisküs kökünün yapışma yerine açılan tünelden bu dikişler dışarı alınır. İpler çekilerek menisküs kök yırtığı redükte edilir ve ipler tibiaya tespit edilir (e). (Dr. Ahmet Öztürk'ün arşivinden)

Abdelkafy ve ark., dışarıdan içeri menisküs tamiri uyguladıkları 41 olguluk serilerinde, hastaları ortalama 11,7 yıl (2-19 yıl) takip etmişler ve klinik olarak değerlendirmişler; beş hastada başarısız sonuç bildirmişlerdir. ${ }^{[19]}$

Mariani ve ark., 22 hastalık serilerinde ön çapraz bağ yaralanmasının eşlik ettiği 22 menisküs yırtığına dıştan içe teknikle tamir uygulamışlar. Hızlandırılmış rehabilitasyon programına dahil edilen hastalarda sonuçlar klinik değerlendirme ve manyetik rezonans görüntüleme ile değerlendirilmiş. Ortalama 28 ay takip sonrasında $\% 77,3$ oranında iyi sonuç bildirmişler, sadece üç hastada tekrar yırtık rapor etmişlerdir. ${ }^{[20]}$

Beş yıldan uzun süreli sonuç veren Van Trommel ve ark.'nın 51 hastalık çalışmalarında sonuçları ikincil bakış artroskopisi, artrografi ve manyetik rezonans görüntüleme ile değerlendirmişler ve \%76 iyi sonuç bildirmişlerdir. \%76 iyi sonuca rağmen bu hastaların sadece \% 45 'inde tam meniskal iyileşme saptanmıştır. \%24 olarak bildirilen iyileşmeyen gruptaki tüm yırtıkların menisküs arka 1/3 yırtıkları olduğunu, arka boynuza dıştan içe tekniği ile tamir uygulandığında dikişlerin oblik koyulmasının optimal olmayan kuvvetlere neden olup iyileşme oranlarını düşürdüğünü savunmuşlardır. ${ }^{[21]}$

Hantes ve ark. dıştan içe, içten dışa ve tamamı içerde tekniği karşılaştırdıkları çalışmalarında, 57 hastanın 22 aylık sonuçlarını yayımlamışlardır. Değerlendirme, klinik göstergelere göre yapılmıştır. On yedi hastada uygulanan dıştan içe tekniğinde $\% 100$ başarı bildirmelerine karşın, bu oran içten dışa tekniğinde \%95, tamamı içerde tekniğinde \%65'lerde kalmıştır. Ameliyat süreleri değerlendirildiğinde dıştan içe grupta 38,5 
dakika (dk), içten dışa grupta 18,1 dk, tamamı içerde grupta 13,6 dk olarak rapor edilmiştir. Dıştan içe teknik uygulanan bir hastada geçici safen sinir hasarına karşı, içten dışa uygulanan üç hastada safen sinir geçici hasarı bildirilmiştir. Bu hastaların şikâyetlerinin ameliyat sonrası 4. ayda geçtiği bildirilmiştir. ${ }^{[22]}$

Venkatachalam ve ark., 59 hastada 62 tamiri değerlendirdikleri çalışmalarında, 21 aylık takip sonuçlarını yayımlamışlardır. Hastaların subjektif değerlendirmelerine dayanan bu çalışmada başarı oranı \%66 bulunmuştur. ${ }^{[23]}$

Son olarak Dave ve ark., dıştan içe teknik sonuçlarını inceleyen meta-analizlerinde başarı oranının \%50 ile \%91 arasında değiştiğini rapor etmişlerdir. Başarı oranının bu kadar değişkenlik göstermesini, kullanılan değerlendirme ölçütlerinin farklılığına bağlamışlardır. ${ }^{24]}$

\section{SONUÇ}

1985 yılında tanımlanmasından itibaren, dıştan içe menisküs tamir tekniğinin küçük kesiler kullanılan, düşük nörovasküler yaralanma riski olan ve özellikle menisküs ön 2/3 yırtıklarında yüksek oranda başarılı sonuçlar veren bir uygulama olduğunu göstermektedir. Bunun yanında menisküs posterior $1 / 3$ yırtıklarında yüksek iyileşmeme oranı ve yüksek nörovasküler yaralanma riski nedeniyle pek tercih edilmemektedir.

Dıştan içe menisküs tamir tekniği ucuz, kolay bulunabilen malzemelerle uygulanabilen, öğrenmesi kolay bir yöntemdir.

\section{Teşekkür}

Medikal çizimler için Dr. Ahmet Öztürk'e teşekkür ederiz.

\section{KAYNAKLAR}

1. Nepple JJ, Dunn WR, and Wright RW. Meniscal repair outcomes at greater than five years: a systematic literature review and meta-analysis. J Bone Joint Surg Am 2012;94(24):2222-7. Crossref

2. Jarit GJ, Bosco JA 3rd. Meniscal repair and reconstruction. Bull NYU Hosp Jt Dis 2010;68(2):84-90.

3. Annandale T. An operation for displaced semilunar cartilage. 1985. Clin Orthop Relat Res 1990;(260):3-5.

4. DeHaven KE, Lohrer WA, Lovelock JE. Long-term results of open meniscal repair. Am J Sports Med 1995;23(5):524-30. Crossref

5. Warren RF. Arthroscopic meniscus repair. Arthroscopy 1985;1(3):170-2. Crossref

6. Henning CE, Lynch MA, Yearout KM, Vequist SW, Stallbaumer RJ, Decker KA. Arthroscopic meniscal repair using an exogenous fibrin clot. Clin Orthop Relat Res 1990;(252):6472. Crossref
7. Wolf BR, Cohen DB, Rodeo SA. Outside-in meniscal repair. Techniques in Knee Surgery 2004;3(1):19-28. Crossref

8. Tenuta JJ, Arciero RA. Arthroscopic evaluation of meniscal repairs. Factors that effect healing. Am J Sports Med 1994;22(6):797-802. Crossref

9. Cho $\mathrm{JH}$. A modified outside-in suture technique for repair of the middle segmentof the meniscus using a spinal needle. Knee Surg Relat Res 2014;26(1):43-7. Crossref

10. Zhang Z, Arnold JA, Williams T, McCann B. Repairs by trephination and suturing of longitudinal injuries in the avascular area of the meniscus in goats. Am J Sports Med 1995;23(1):35-41. Crossref

11. Rankin CC, Lintner DM, Noble PC, Paravic V, Greer E. A biomechanical analysis of meniscal repair techniques. Am J Sports Med 2002;30(4):492-7. Crossref

12. Kohn D, Siebert W. Meniscus suture techniques: a comparative biomechanical cadaver study. Arthroscopy 1989;5(4):324-7. Crossref

13. Aşık M, Şener N. Failure strength of repair devices versus meniscus suturing techniques. Knee Surg Sports Traumatol Arthrosc 2002;10(1):25-9. Crossref

14. Johnson LL. Meniscus Repair: The Outside-In Technique. In: Jackson DW, editor. Master Techniques in Orthopaedic Surgery: Reconstructive Knee Surgery, 3rd ed. Philadelphia: Lippincott Williams \& Wilkins; 2008.

15. Cooper DE, Arnoczky SP, Warren RF. Arthroscopic meniscal repair. Clin Sports Med 1990;9(3):589-607.

16. Rodeo SA, Warren RF. Meniscal repair using the outside-toinside technique. Clin Sports Med 1996;15(3):469-81.

17. Dowdy PA, Miniaci A, Arnoczky SP, Fowler PJ, Boughner DR. The effect of cast immobilization on meniscal healing. An experimental study in the dog. Am J Sports Med 1995;23(6):721-8. Crossref

18. Morgan CD, Wojtys EM, Casscells CD, Casscells SW. Arthroscopic meniscal repair evaluated by second-look arthroscopy. Am J Sports Med 1991;19(6):632-8. Crossref

19. Abdelkafy A, Aigner $N$, Zada M, Elghoul $Y$, Abdelsadek $H$, Landsiedl F. Two to nineteen years follow-up of arthroscopic meniscal repair using the outside-in technique: a retrospective study. Arch Orthop Trauma Surg 2007;127(4):245-52. Crossref

20. Mariani PP, Santori N, Adriani E, Mastantuono M. Accelerated rehabilitation after arthroscopic meniscal repair: a clinical and magnetic resonance imaging evaluation. Arthroscopy 1996;12(6):680-6. Crossref

21. van Trommel MF, Simonian PT, Potter HG, Wickiewicz TL. Different regional healing rates with the outside-in technique for meniscal repair. Am J Sports Med 1998;26(3):446-52. Crossref

22. Hantes ME, Zachos VC, Varitimidis SE, Dailiana ZH, Karachalios T, Malizos KN. Arthroscopic meniscal repair: a comparative study between three different surgical techniques. Knee Surg Sports Traumatol Arthrosc 2006;14(12):1232-7. Crossref

23. Venkatachalam S, Godsiff SP, Harding ML. Review of the clinical results of arthroscopic meniscal repair. Knee 2001;8(2):129-33. Crossref

24. Dave LYH, Caborn DNM. Outside-in meniscus repair: the last 25 years. Sports Med Arthrosc 2012;20(2):77-85. Crossref 